\title{
'Stakeholders' Perceptions of Corporate Social Responsibility: Empirical Evidences from Iran
}

\author{
Mahdi Salehi (corresponding author) \\ Assistant Professor, Accounting and Management Department \\ Zanjan University, Zanjan, Iran \\ Zanjan Province, Iran \\ Tel: 989-121-425-323_E-mail: Mahdi_Salehi54@yahoo.com \\ Postal Address: D.N. 1, Naghilo Alley, Hidaj City, Zanjan Province, Zanjan, Iran \\ Zhila Azary \\ Research Staff, Ministry of Agriculture \\ Zanjan Branch, Zanjan, Iran \\ Zanjan Province, Iran
}

"We never get what we wish" (Salehi, 2007).

\begin{abstract}
Corporate Social Responsibility (CSR) is very high on corporations' agenda in recent years. CSR means different things to different stakeholders but generally refers to saving people, communities and the environment way that goes beyond what is legally required of a firm. In such a position majority of stakeholders look for higher CSR. However, according to this survey there is an expectation gap between actual level of CSR and expected level from the viewpoint of stakeholders. In this survey the authors became to conclusion Iranian corporate sectors have very less CSR from the viewpoint of third parties. It not only damaged third parties confidence but corporate performance also.
\end{abstract}

Keywords: Corporate, Corporate Social Responsibility, Iran

\section{Introduction}

Since the 1970s, corporations have addressed business ethics in various ways, including the introduction of compliance programs and managers, the addition of board-level ethics committees, the development of codes of conduct, the preparation and dissemination of values statements, the hiring of corporate social responsibility and training programs of all kinds. However, profit seeking companies have been setting up operations in developing countries for numerous reasons, including cheaper labour, new opportunities, and access to resources, all for the ultimate objective of increasing profits. Unfortunately, many of these companies, especially in developing countries are not following ethical practices or conforming to labour or environmental standards, leading to a global response from concerned citizens (Kapstein, 2001; Cragg and Greenbaum, 2002).

Globalization has opened up new opportunities but it has also exposed the world to new risks. Companies are confronted with new dynamics since the linkages between the social, environmental, political and economic roles of businesses are increasing.

Mergers, deregulation and privatization have resulted in the creation of large corporations that in some cases have more economic power than sovereign countries. This has created a shift in responsibility and public expectations towards these corporations have grown.

The challenge for corporations is to maintain and/or increase profits and respond to the new societal expectations at the same time. Managing these two issues, which seem to contradict each other, requires the development and implementation of strategies that will have positive impacts for both the corporation and society. One way of linking 
economics and social well being is through the development and implementation of CSR.

Carroll (1999) note, the CSR concept has had a long and diverse history in the academic literature. A general view of CSR is for companies to be accountable to their stakeholders. Stakeholders are generally employees, customers, suppliers, communities, etc. Corporate Social Responsibility activities can consist of being responsible to employees, by, for example, developing and implementing policies which improve working conditions for employees in the firm. CSR can also consist of being accountable to the community where the company operates, by, for example, volunteering company personnel to the community. CSR can also involve developing policies which are environmentally friendly, for example, setting up a recycling system. The broad understanding is that CSR has three principles which represent environmental, social and economic dimensions (Kingston and Wagner, 2004). The terminology for CSR also varies; some companies refer to it as corporate responsibility, social responsibility, corporate citizenship, sustainability, or sustainable development (Overton, 2004).

\subsection{Definition of CSR:}

CSR has emerged as the business issue of the 21 st century and has been studied for over 50 years. To this day academics do not have a consensus on its definition (Wood, 1991; Carroll, 1991) and it has been frequently assigned to the field of business ethics and conduct.

Publications, definitions and references to CSR started as early as the 1950s. One of the pioneer books on the topic of CSR was written by Howard in 1953, titled the "Social Responsibilities of the Businessman". This was one of the pioneer books on social responsibility for businesses and highlighted a company's role beyond the financial benefits.

Common definition of the social responsibility of businessmen was "it refers to the obligations of businessmen to pursue those policies to make those decisions or to follow those lines of relation which are desirable in terms of the objectives and values of our society" (Carroll 1999:270).

One of the first writers of the 60s who defined CSR is Keith Davies. He argued that CSR refers to "the firm's consideration of, and response to, issues beyond the narrow economic, technical and legal requirements of the firm" (Davies 1973: 312). Frederick (1960) was also a major contributor to the emerging definition. He stated, "Social responsibility means that businessmen should oversee the operation of an economic system that fulfills the expectations of the people. And this means in turn that the economy's means of production should be employed in such a way that production and distribution should enhance total socio-economic welfare (Frederick 1960:60). Social responsibility in the final analysis implies a public posture toward society's economic and human resources and a willingness to see that those resources are used for broad social ends and not simply for the narrowly circumscribed interests of private persons and firms". The definitions of CSR in the 60s were an attempt to link society and businesses, defining society in the broadest terms. There was no specific relation to the ecology, environment, or community. In the 70s, the number of authors writing and making reference to CSR started to multiply. The idea and inclusion of stakeholders began to appear; Johnston (1971: 50) stated that "a socially responsible firm is one whose managerial staff balances a multiplicity of interests instead of striving only for larger profits for its stockholders. A responsible enterprise also takes into account employees, suppliers, dealers, local communities, and the nation". One of the most important contributions to the definition of CSR was made by the Committee for Economic Development (CED) in 1971, the CED articulated a triple concentric definition of social responsibility; "The inner circle includes the clear-cut basic responsibilities for the efficient execution of the economic function products, jobs, and economic growth. The intermediate circle encompasses responsibility to exercise his economic function with a sensitive awareness of changing social values and priorities: for example to environmental conservation, hiring and relations with employees, and more rigorous expectations of customers for information, fair treatment and protections from injury. "The outer circle outlines newly emerging and still amorphous responsibilities that business should assume to become more broadly involved in actively improving the social environment" Committee for Economic Development (CED 1971: 15). This definition provides a more integrated approach between the business and employees, society (again as a whole) and the environment. Eilbert and Parket (1973) introduced the concept of community in their CSR definition, using the term "neighborhood"; "perhaps the best way to understand social responsibility is to think of it as good neighborliness. The concept involves two phases. On the one hand, it means not doing things that spoil the neighborhood, on the other; it might be expressed as the voluntary assumption of the obligation to help solve neighborhood problems. Those who find neighborliness an awkward or coy concept may substitute the idea that social responsibility means the commitment of a business or business, in general, to an active role in the solution of broad social problems such as racial discrimination, pollution, transportation, or urban decay ". Carroll (1979) offered the following definition of CSR "The social responsibility of business encompasses the economic, legal, ethical, and discretionary (or philanthropic) expectation that society has of organizations at a given point in time". In the $80 \mathrm{~s}$ and 90 s there were fewer definitions but more efforts to measure and conduct research for the purpose of operationalizing CSR.

In an attempt to relate corporate social responsibility, responsiveness and business ethics, Epstein (1987) provided the following definition "CSR relates primarily to achieving outcomes from an organization's decisions concerning specific 
issues or problems which by some normative standard have beneficial rather than adverse effects on pertinent corporate stakeholders. The normative correctness of the products of corporate action has been the main focus of CSR". He pointed out that the three concepts are closely related and overlap and introduced a new term "corporate social policy process" by merging together his definitions for corporate social responsiveness and business ethics. He stated "the nub of the corporate social policy process is the institutionalization within business organization of the following three elements; business ethics, corporate social responsibility and corporate social responsiveness".

CSR refers to a company's commitment to operate in an economically and environmentally sustainable manner, while acknowledging the interests of a variety of stakeholders and maximizing economic, social and environmental value. It is a holistic concept that can mean different things to different groups and stakeholders. Central to the operations is the belief that both businesses and individuals have responsibilities (Lee, 1997). It's about doing business in an economically, socially and environmentally responsible way - a way that involves all stakeholders including employees, customers and communities. CSR is determined by an organization's policy and continuous action in such areas as employee relations, diversity, community development, environment, international relationships, marketplace practices, fiscal responsibility and accountability. CSR isn't just about philanthropy and volunteerism. It's about having a mindset and a corporate culture that sees value in interacting with society above and beyond simply satisfying customers and shareholders. Some advocates of CSR prefer not to define the term, mentioning that it is more a process than a specific program (Kotter and Heskett, 1992). Another author defines CSR as the measure of a company's impacts on the quality of life of its stakeholders. Thus CSR is the sum of actions taken in the interest of society, the actions which have benefits both inside and outside a company (Bloom, 2003). CSR is based on "the legitimacy with society, public responsibility within the organization and managerial discretion by each individual with the organization" (Stanwick and Stanwick; 1998). According to Wilson (1997), the "role and responsibility of business extends well beyond the critical importance of wealth creation". He goes as far as saying that "a profitable business sector is vital to funding the standard of living and quality of life to which society aspires". McIntosh et al. (1998) asserts that businesses are socially responsible when they consider and act on the needs and demands of their different stakeholder groups. Finally the World Business Council on Sustainable Development (WBCSD) defines CSR as "The continuing commitment by business to behaving ethically and contributing to economic development while improving the quality of life of the workforce and their families as well as of the community and society at large" (Wawryk, 2003). At the other end of the spectrum of corporate responsibility are the more fundamentalist views of Friedman (1970) and Levitt (1983) who argue that business has only one responsibility and that is to make a profit for its shareholders. Any mission beyond this must be considered fraudulent on the part of the organization's managers. They also believe that corporations function to make a profit and governments should worry about social responsibility. This argument varies considerably with most of the literature and there have been wide criticisms and debates since Friedman published his comments.

Today, we are held to new standards for corporate citizenship, human rights, and the environment that are no less rigorous than the financial requirement of the investment in communities" (Williams 2002: 26). Considerable change has occurred since Friedman's comments. Society in general has become more demanding in the selection of products and services and in addition they demand that companies exercise moral judgment towards communities, societies and the environment. Friedman may have neglected to understand the change that was occurring at the time and failed to recognize that the move toward CSR was not a gimmick or temporary trend but a permanent cultural change in society.

Finally, American Petroleum Institute International Petroleum Industry Environmental Conservation Association API/IPIECA defines social responsibility specifically for the oil and gas industry "as the voluntary commitment by business to manage its activities in a responsible way. "Oil and gas companies aim to be active and responsible members of the communities in which they operate and to contribute to economic development while improving the quality of life" (2003).

\subsection{Evolution in CSR}

The emergence of accountability, governance, responsibility and transparency for the private sector has created different approaches to social responsibility and business conduct. In the era of President Johnson in the United States, the phrase "quality of life" was introduced and changed the whole significance of consumer products and consumerism. The notion of quality products, quality of working life and quality of the environment became issues for the public and corporations had to react to this new trend by introducing products that were safe. Certain business sectors such as nuclear power and tobacco started to be questioned. There was recognition of the need to have ecological, environmental, economical and social balance which meant that the private sector was seen as the actor to bring solutions to these consumer concerns. Companies started to create and publish new policies and expand internal training and communication programs to promote compliance. They started to lobby to influence public opinion and the government. Some companies initiated "catching-up" initiatives such as establishing equal employment opportunities for minorities. Large corporations began to go public about corporate social responsibilities and publish some of their efforts, but they also made public that "any approach to corporate responsibility must begin with the practical recognition that the corporation must be profitable 
enough to provide shareholders a return that will encourage continuation of investment" (Wilson 2000: 12). More successful initiatives included the incorporation of social issues in the company's traditional annual reports. General Motors used a successful strategy in 1971 inviting educators and representatives of foundations and investment institutions to a conference to explain the progress made by General Motors in areas of public concern and obtain participants' comments.

However, it was not until the late 1970's that companies began to react more pro actively to corporate social responsibility issuing affirmative action guidelines, for example, for women's rights and including corporate social responsibility in strategic planning, which required companies to include all stakeholders, consumers, shareholders, employees, community and the general public. Some companies established board of directors' committees to deal with corporate responsibility issues. Others established staff groups to examine and raise questions related to these issues. The Business Roundtable documented some policy instruments introduced by companies, which included;

- A written code of conduct;

- Well-defined corporate policies with regard to such matters as executive compensation, fair pay, equal employment opportunity, personal privacy and freedom of expression;

- A continuing focus on corporate impact on the environment, health and safety in the workplace, and the impact of plant openings and closings on communities and employees;

- Written policy on disclosure;

- Continuing concern about product quality, acceptable pricing policies, and ethics in advertising, and

- A high priority for high level attention to the size and direction of corporate philanthropy.

\section{Literature review}

Societal expectations for businesses have developed over time and there have been periods where they have been more noticeable than others. Traditionally, corporations were viewed as a means of obtaining products, services and employment. Increasingly however, the public are demanding environmental and social benefits from corporations. Formal writing on CSR is a product of the 20th Century and references on the subject started as early as the 1930s, including Bernard's (1938) the Function of the Executive (Carroll, 1999).

In the $60 \mathrm{~s}$ issues about minority rights, women's rights, consumerism, environmentalism, corporate support for the Vietnam War and other factors brought about a new cultural revolution in society. These developments initiated the corporate social responsibility movement.

Schumacher (1973) revolutionized the idea of development and global economics. As an economist he saw the link between society, environment and economics and presented unconventional theories for achieving improved quality of life for people. Schumacher said "The business man, as a private individual, may still be interested in other aspects of life - perhaps even in goodness, truth, and beauty - but as a business man he concerns himself only with profits". He challenged the conventional idea that the only responsibility of the enterprise is to make profits. The Corporate Social Responsibility movement was an early response to an article published in 1970 by Friedman stating that the "social responsibility of business is to increase its profits". This argument was in 1963 the owner transferred the control of the company to a collectivity and established socially responsible restrictions.

Schumacher's views of idealistic businesses is part of what we call today good business practice, corporate social responsibility, responsiveness, governance, business ethics and many other interrelated concepts. It is the movement which makes businesses more accountable and responsible for the quality of life of their stakeholders. In other words these concepts are not new and private enterprises throughout the world had been practicing them before governments began to institutionalize the concept.

The impetus for change is increasing through shifting social values, increasing consumer and shareholder activism, ease of technological communication, strengthening local and international citizen action, depleting natural resources, and a growing recognition that the benefits of globalization are not shared equally, mostly profiting the richer countries.

Wilson (2000) describes the paradigm shift of society's value as a "New Reformation", a reordering of public and private value systems, and sums it up as follows:

- From considerations of quantity (more) to considerations of quality (better);

- From the concept of independence, toward the concept of interdependence (of nations, institutions, individuals, and all natural species);

- From mastery over nature toward living in harmony with it;

- From competition toward cooperation;

- From the primacy of technical efficiency toward considerations of social justice and equity; 
- From the dictates of organizational convenience toward the aspirations of self development in an organization's members;

- From authoritarianism toward participative management, and

- From uniformity and centralization toward diversity, decentralization, and pluralism (Wilson 2000; 8).

\section{Research methodology}

The main purpose of this study is to determine the actual level as well as expected level of various groups in Iran regarding different aspects of CSR. In addition, the study attempt to provide answers to following research questions:

RQ1: What is the perception of different groups in Iran about CSR?

RQ2: Is there any differences between actual level of CSR and expected level among respondents?

To provide clear answers to the research questions, a Five-Point Scale Likert questionnaire adopted from previous researches (Al-khater and Naser, 2003) in terms of "Strongly agree" to "strongly disagree". The questionnaire was distributed to the following groups in Iran: External auditors, internal auditors, accountants, bankers, investors, and academician. The selection of these groups was based on the random selection. These groups are also somehow companies' beneficiaries.

The questionnaire separated into two parts, namely the first part contains general information on the respondents, background profile and the second part of the questionnaire was related respondents' opinion about different aspects of CSR which actual it is existed as well as the expected levels of respondents groups. The second part was sub-divided into five areas for determining actual level of CSR which it is already practice in Iran as well as expected level from the viewpoint of respondents groups. This part was cover five areas namely; CSR towards customers, CSR towards employees, CSR towards suppliers, CSR towards broader community and CSR towards environment.

Table No.1 shows the number of questionnaires that were distributed, the number returned for each group, and the overall response rate.

\section{Insert Table 1}

The largest number of received questionnaire was academicians numbering 88 and they represented 88 per cent. Further, 80 percent of questionnaires were received by various respondents. The questionnaire sought information about the sample groups' gender, age and level of education. The vast majority of the respondents ( 82 per cent) were male. Out of cent percent 58 per cent were less than 35 years. A total of 71 per cent of the participants indicated that they hold a bachelor degree in accounting or related fields in contrast, 20 per cent of participants indicated that they hold a master degree in accounting or related fields. Only 9 per cent of the participants indicated that either they hold $\mathrm{PhD}$ or doing $\mathrm{PhD}$ in accounting or related fields.

\subsection{Statistical Techniques}

To analyzing data, descriptive statistics that include frequencies, mean and median were adopted. Further, to analyzing differences between actual level and expected level of various groups about different aspects of CSR Wilcoxon Test is employed.

Insert Table 2

Table 2 shows the results of perceptions of the respondents about CRS towards customers was assigned the mean value of 2.72 as against the expected mean value of 3.43 and there was an expectation gap of 0.71 . The actual CRS was found to be moderately high with the mean value of 2.83 with regard to product safety and of 2.84 for fair marketing practices. The expectation gap was found to be highest with regard to product safety with the mean value of 3.52 .

The test shows that there were significant differences between the actual and expected value of all the variables $\mathrm{Z}=$ $0.000(<0.05)$.

\section{Insert Table 3}

CSR towards employees was tested in table 3 with five variables, viz., Equal opportunities, Health and safety; Performance towards local employees, Developing skills and Employment security. CSR towards employees was assigned the overall actual mean value of 3.16 and expected mean value stood at 3.42 resulting in an expectation gap of 0.26 .

The test shows that there were significant differences between the actual and expected value of all the variables $\mathrm{Z}=0.000(<0.05)$ except employment security $(>0.05)$.

Insert Table 4

CRS towards suppliers in table 4 was tested with four components consisting of Purchasing ethics, Preference towards local suppliers, Social consciousness and environmental consciousness. The actual and expected mean values at grand 
mean level were moderately high with the values of 3.24 and 3.74 with an expectation gap of 0.5 . The highest actual mean value and expected mean value with regard to the variable Environmental consciousness were 3.43 and 4.08 respectively.

The test shows that there were significant differences between the actual and expected value of all the variables $Z=$ $0.000(<0.05)$.

Table 5 presents the CSR towards broader community, which includes three variables. CSR towards broader community was assigned the actual mean grand mean value of 2.80 as against the expected mean value of 3.59 and expectation gap was found to be the mean value of 0.79 .

Insert table 5

The highest expectation gap was found to be the Sustainability of community with the mean value difference of 0.93 as against the least expectation gap of 0.63 with regard to Community consultation. The test shows that there were significant differences between the actual and expected value of all the variables $Z=0.000(<0.05)$.

Table 6 depicts the levels CSR towards environment the actual grand mean value stood at 2.90 and the expected grand mean value was 3.56 resulting in the expectation gap of 0.66 .

Insert Table 6

The actual mean value of pollution was low at 2.83. The highest expectation gap was highlighted in urban renewal and the gap between actual expected mean values stood at 1.01. The least expectation gap was evidenced in energy usage and the gap between the mean values stood at 0.46 . The test shows that there were significant difference between the actual and expected value of all the variables $Z=0.000(<0.05)$.

\section{Conclusions and remarks}

CSR is important to various users of corporate information such as employees, customers, local community, and government and its agencies, pressure groups and society in whole (Al-khater and Naser, 2003). In this study, an attempt was made to investigate the actual levels as well as perception levels of various user groups in Iran regarding CSR. For user groups took part in the survey, namely, external auditors, internal auditors, accountants, bankers, investors and academician. According to this result almost in all statements there is a expectation gap between the actual level of CSR and expected level among the participants. The results of this survey show that Iranian corporate sectors had attention to CRS; however according to viewpoint of third parties it is very far from expected level. In addition, the authors become to conclusion that if such condition carried out by Iranian corporate sectors, it will create big problem not only to stakeholders' benefits but to corporate performance also. To solving such serious problem the Iranian legislators should force corporate sectors for following more corporate responsibilities at large scale.

\section{References}

Al-khater, K. \& Kamal N. (2003). "Users' Perceptions of Corporate Social Responsibility and Accountability: Evidence from Emerging Economy”, Managerial Auditing Journal, Vol.18. No.6. pp: 538-548.

API/IPIECA (2003), Compendium of Sustainability Reporting Practices and Trends for the Oil and Gas Industry, IPIECA, APRIL, 2003.

Bernard, C.I. (1938). The Functions of the Executive. Cambridge, MA: Harvard University Press.

Bloom, R. (2003). "Ethical Funds Change with the Times", The Globe and Mail's Weekly Report on Personal Finance", The Globe and Mail, Saturday, March 8, 2003, pp. Cl and C8.

Carroll, A.B. (1999). "Corporate Social Responsibility: Evolution of a Definitional Construct", Business and Society, Volume 38, No.3, September, pp. 268-295.

Carroll, AB. (1979). "A Three-Dimensional Conceptual Model of Corporate Social Performance", Academy for Management Review, Vol.4, pp: 497-505.

Carroll, AB. (1991). "The Pyramid of Corporate Social Responsibility: Towards the Moral Management of Organizational Stakeholders", Business Horizons, Vol. 34, No. 4, pp: 39-48.

Committee for Economic Development. (1971), Social Responsibilities of Business Corporations, New York.

Cragg, W \& Alan., G. (2002). "Reasoning about Responsibilities: Mining Company Managers on What Stakeholders are Owed", Journal of Business Ethics, Vol. 39, pp: 319-335.

Davis, K. (1973). "The Case for and Against Business Assumption of Social Responsibilities", Academy of Management Journal, Vol. 16, June, pp: 312-322.

Eilbert, H. \& I.R. Parket. (1973). “The Current Status of Corporate Social Responsibility”, Business Horizons, Vol.16, August, pp: 5-14. 
Epstein, E.M. (1987). “The Corporate Social Policy Process: Beyond Business Ethics, Corporate Social Responsibility and Corporate Social Responsiveness", California Management Review, 29, No. 19, pp. 114-128.

Frederick, W.C. (1960). "The Growing Concern over Business Responsibility”, California Management Review, Vol. 2 , Summer, pp: 54-61.

Friedman, M. (1970). "The Social Responsibility of Business is to Increase its Profits", New York Times Magazine, September, Vol. 13, pp: 122-126.

Johnston, H.L. (1971). Business in Contemporary Society: Framework and Issues. Belmont, CA: Wadsworth.

Kapstein, Ethan B. (2001). “The Corporate Ethics Crusade”, Foreign Affairs, Volume 80, No.5, pp. 105-119.

Kingston, P., and Jay W. (2004). Sustainable and HSE/CSR Performance: The Role of Leadership, the Seventh SPE International Conference on Health, Safety, and Environment in Oil and Gas Exploration and Production. Calgary, Alberta, Canada, 29-31 March 2004.

Kotter, J.P. and J.L. Heskett. (1992). Corporate Culture and Performance, The Free Press, New York, NY.

Lee, M. (1997). Responsible Business Development through Community Economic Development and Corporate Social Responsibility, Burnaby, BC: CED Centre, Simon Fraser University.

Levitt, T. (1983). "The Dangers of social Responsibility", In T.L. Beauchamp \& N.E. Bowie (eds.) Ethical Theory and Business (pp.83-86). Englewood Cliffs, New Jersey: Prentice-Hall Inc.

McIntosh, M., D., Leipziger, K., Jones, G. \& Coleman (1998), Corporate Citizenship. London. GB: Pitman.

Overton, C. (2004). Corporate Social Responsibility - Capturing the Value, the Seventh SPE International Conference on Health, Safety, and Environment in Oil and Gas Exploration and Production. Calgary, Alberta, Canada, 29-31 March 2004.

Salehi, Mahdi. (2007). "Reasonableness of Audit Expectation Gap: possible Approach to Reducing”, Journal of Audit Practice, Vol.4, No.3, pp: 50-59.

Schumacher, E.F. (1973). Small is Beautiful- Economics as if People Mattered, Hartley and Marks Publishers Inc.

Stanwick, P. \& Stanwich., S. (1998). "The Relationship between Corporate Social Performance, and Organizational Size, Financial Performance, and Environmental Performance: An empirical examination”, Journal of Business Ethics, Vol.17, pp: 195-204.

Wawryk, A. (2003). Regulating Transnational Corporations through Corporate Codes of Conduct, p. 53-78 in Transnational Corporations and Human Rights, edited by Jedrzej George Frynas and Scott Pegg, Palgrave Macmillan Ltd.

Williams, B. (2002). “Oil/Industry Adapting to Evolving New Paradigm on Corporate Governance”, Accountability, Oil and Gas Journal, October 28, pp.20-32.

Wilson, A. (1997). "Business and its social responsibility, In Davies, P. (Ed), Current Issues in Business Ethics, pp. 50-60. London, GB: Routledge.

Wilson, Ian. (2000). The New Rules of Corporate Conduct - Rewriting the Social Charter. Copyright @ 2000 by Ian Wilson. Quorum Books, Westport, CT - Greenwood Publishing Groups, Inc.

Wood, D. 1. (1991). “Towards Improving Corporate Social Performance”, Business Horizons, Vol. 34, No. 4, pp: 66-73. 
Table 1. Questionnaire Distributed Profile

\begin{tabular}{|c|c|c|c|}
\hline Target Group & $\begin{array}{c}\text { Distributed } \\
\text { Questionnaire }\end{array}$ & $\begin{array}{c}\text { Received } \\
\text { Questionnaire }\end{array}$ & $\begin{array}{c}\text { Response } \\
\text { Rate } \\
\text { (Percentage) }\end{array}$ \\
\hline External auditors & 100 & 82 & 82 \\
\hline Internal auditors & 100 & 78 & 78 \\
\hline Accountants & 100 & 72 & 72 \\
\hline Bankers & 100 & 75 & 75 \\
\hline Investors & 100 & 85 & 85 \\
\hline Academician & 100 & 88 & 88 \\
\hline Total & 600 & 480 & 80 \\
\hline
\end{tabular}

Table 2. CSR towards customers

\begin{tabular}{|c|c|c|c|c|c|c|c|c|}
\hline \multirow{2}{*}{$\begin{array}{l}\dot{0} \\
\dot{\sim}\end{array}$} & \multirow{2}{*}{$\begin{array}{l}\text { Companies have } \\
\text { responsibilities towards } \\
\text { customers }\end{array}$} & \multirow{2}{*}{ 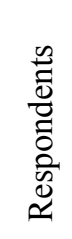 } & \multirow{2}{*}{ 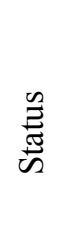 } & \multicolumn{2}{|c|}{$\begin{array}{l}\text { Paired Samples } \\
\text { Statistics }\end{array}$} & \multirow{2}{*}{$\begin{array}{l}\text { Paired } \\
\text { Differences }\end{array}$} & \multicolumn{2}{|c|}{ Paired Samples Test } \\
\hline & & & & Mean & $\mathrm{SD}$ & & $\begin{array}{l}\text { Wilcoxon } \\
\text { Test }\end{array}$ & $Z^{*}$ \\
\hline \multirow{2}{*}{1} & \multirow{2}{*}{ Fair trading practices } & \multirow{2}{*}{480} & A & 2.58 & 1.06 & \multirow{2}{*}{-0.88} & \multirow{2}{*}{-14.961} & \multirow{2}{*}{0.000} \\
\hline & & & $\mathrm{E}$ & 3.46 & 1.25 & & & \\
\hline \multirow{2}{*}{2} & \multirow{2}{*}{$\begin{array}{l}\text { Fair marketing } \\
\text { practices }\end{array}$} & \multirow{2}{*}{480} & A & 2.84 & 1.09 & \multirow{2}{*}{-0.65} & \multirow{2}{*}{-13.215} & \multirow{2}{*}{0.000} \\
\hline & & & $\mathrm{E}$ & 3.49 & 1.26 & & & \\
\hline \multirow{2}{*}{3} & \multirow{2}{*}{ Product safety } & \multirow{2}{*}{480} & A & 2.83 & 1.14 & \multirow{2}{*}{-0.69} & \multirow{2}{*}{-13.154} & \multirow{2}{*}{0.000} \\
\hline & & & $\mathrm{E}$ & 3.52 & 1.30 & & & \\
\hline \multirow{2}{*}{4} & \multirow{2}{*}{ Services } & \multirow{2}{*}{480} & A & 2.62 & 1.08 & \multirow{2}{*}{-0.63} & \multirow{2}{*}{-12.089} & \multirow{2}{*}{0.000} \\
\hline & & & $\mathrm{E}$ & 3.25 & 1.31 & & & \\
\hline \multirow{2}{*}{\multicolumn{3}{|c|}{ Grand mean }} & A & 2.72 & & \multirow{2}{*}{-0.71} & & \\
\hline & & & $\mathrm{E}$ & 3.43 & & & & \\
\hline
\end{tabular}

*Significance (2-tailed), Note: A=Actual, E=Expectation 
Table 3. Companies' responsibilities towards employees

\begin{tabular}{|c|c|c|c|c|c|c|c|c|}
\hline \multirow{2}{*}{$\begin{array}{l}\dot{0} \\
\dot{z} \\
\dot{n}\end{array}$} & \multirow{2}{*}{$\begin{array}{l}\text { Companies have } \\
\text { responsibilities } \\
\text { towards employees }\end{array}$} & \multirow{2}{*}{ 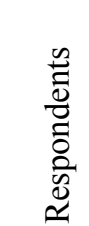 } & \multirow{2}{*}{$\sum_{\tilde{E}}^{\infty}$} & \multicolumn{2}{|c|}{$\begin{array}{l}\text { Paired Samples } \\
\text { Statistics }\end{array}$} & \multirow{2}{*}{$\begin{array}{l}\begin{array}{l}\text { Paired } \\
\text { Differences }\end{array} \\
\text { Mean }\end{array}$} & \multicolumn{2}{|c|}{ Paired Samples Test } \\
\hline & & & & Mean & SD & & Wilcoxon Test & $Z^{*}$ \\
\hline \multirow{2}{*}{1} & \multirow{2}{*}{ Equal opportunities } & \multirow{2}{*}{480} & A & 3.24 & 1.384 & \multirow{2}{*}{-0.25} & \multirow{2}{*}{-5.062} & \multirow{2}{*}{0.000} \\
\hline & & & E & 3.49 & 1.443 & & & \\
\hline \multirow{2}{*}{2} & \multirow{2}{*}{ Health and safety } & \multirow{2}{*}{480} & $\mathrm{~A}$ & 3.28 & 1.361 & \multirow{2}{*}{-0.33} & \multirow{2}{*}{-11.423} & \multirow{2}{*}{0.000} \\
\hline & & & $\mathrm{E}$ & 3.61 & 1.287 & & & \\
\hline \multirow{2}{*}{3} & \multirow{2}{*}{$\begin{array}{l}\text { Performance towards } \\
\text { local employees }\end{array}$} & \multirow{2}{*}{480} & $\mathrm{~A}$ & 3.09 & 1.180 & \multirow{2}{*}{-0.49} & \multirow{2}{*}{-9.349} & \multirow{2}{*}{0.000} \\
\hline & & & $E$ & 3.58 & 1.162 & & & \\
\hline \multirow{2}{*}{4} & \multirow{2}{*}{ Developing skills } & \multirow{2}{*}{480} & A & 3.30 & 1.066 & \multirow{2}{*}{-0.34} & \multirow{2}{*}{-12.528} & \multirow{2}{*}{0.000} \\
\hline & & & $\mathrm{E}$ & 3.64 & 1.161 & & & \\
\hline \multirow{2}{*}{5} & \multirow{2}{*}{ Employment security } & \multirow{2}{*}{480} & A & 2.89 & 1.155 & \multirow{2}{*}{0.09} & \multirow{2}{*}{-1.747} & \multirow{2}{*}{0.081} \\
\hline & & & $\mathrm{E}$ & 2.80 & 1.388 & & & \\
\hline \multirow{2}{*}{\multicolumn{3}{|c|}{ Grand mean }} & A & 3.16 & & ก ? & & \\
\hline & & & E & 3.42 & & -0.20 & & \\
\hline
\end{tabular}

*Significance (2-tailed), Note: A=Actual, E=Expectation

Table 4. Companies' responsibilities towards suppliers

\begin{tabular}{|c|c|c|c|c|c|c|c|c|}
\hline \multirow{2}{*}{$\begin{array}{l}\dot{\mathrm{Z}} \\
\dot{n}\end{array}$} & \multirow{2}{*}{$\begin{array}{l}\text { Companies have responsibilities } \\
\text { towards suppliers }\end{array}$} & \multirow{2}{*}{ 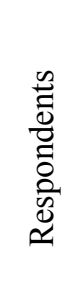 } & \multirow{2}{*}{ 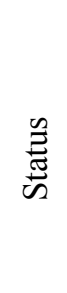 } & \multicolumn{2}{|c|}{$\begin{array}{l}\text { Paired } \\
\text { Samples } \\
\text { Statistics }\end{array}$} & \multirow{2}{*}{$\begin{array}{l}\text { Paired } \\
\begin{array}{l}\text { Differen } \\
\text { ces }\end{array} \\
\text { Mean }\end{array}$} & \multicolumn{2}{|l|}{$\begin{array}{l}\text { Paired } \\
\text { Test }\end{array}$} \\
\hline & & & & Mean & SD & & $\begin{array}{l}\text { Wilcoxon } \\
\text { Test }\end{array}$ & $Z^{*}$ \\
\hline \multirow{2}{*}{1} & \multirow{2}{*}{ Purchasing ethics } & \multirow{2}{*}{480} & $\mathrm{~A}$ & 2.79 & 1.057 & \multirow{2}{*}{-0.6} & \multirow{2}{*}{-11.159} & \multirow{2}{*}{0.000} \\
\hline & & & $\mathrm{E}$ & 3.39 & 1.309 & & & \\
\hline \multirow{2}{*}{2} & \multirow{2}{*}{$\begin{array}{l}\text { Preference towards local } \\
\text { suppliers }\end{array}$} & \multirow{2}{*}{480} & A & 3.38 & 1.250 & \multirow{2}{*}{-0.33} & \multirow{2}{*}{-4.512} & \multirow{2}{*}{0.000} \\
\hline & & & $\mathrm{E}$ & 3.71 & 1.120 & & & \\
\hline \multirow{2}{*}{3} & \multirow{2}{*}{ Social consciousness } & \multirow{2}{*}{480} & $\mathrm{~A}$ & 3.36 & 1.290 & \multirow{2}{*}{-0.43} & \multirow{2}{*}{-8.728} & \multirow{2}{*}{0.000} \\
\hline & & & $\mathrm{E}$ & 3.79 & 1.099 & & & \\
\hline \multirow{2}{*}{4} & \multirow{2}{*}{ Environmental consciousness } & \multirow{2}{*}{480} & $\mathrm{~A}$ & 3.43 & 1.251 & \multirow{2}{*}{-0.65} & \multirow{2}{*}{-13.342} & \multirow{2}{*}{0.000} \\
\hline & & & E & 4.08 & 1.172 & & & \\
\hline \multirow{2}{*}{\multicolumn{3}{|c|}{ Grand mean }} & A & 3.24 & & \multirow{2}{*}{-0.5} & & \\
\hline & & & $\mathrm{E}$ & 3.74 & & & & \\
\hline
\end{tabular}

*Significance (2-tailed), Note: $\mathrm{A}=$ Actual, $\mathrm{E}=$ Expectation 
Table 5. CSR towards broader community

\begin{tabular}{|c|c|c|c|c|c|c|c|c|}
\hline \multirow{2}{*}{$\begin{array}{l}\dot{0} \\
\dot{\sim}\end{array}$} & \multirow{2}{*}{$\begin{array}{l}\text { Companies } \\
\text { responsibilities } \\
\text { broader community }\end{array}$} & \multirow{2}{*}{ 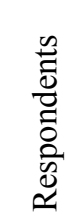 } & \multirow{2}{*}{ 营 } & \multicolumn{2}{|c|}{$\begin{array}{l}\text { Paired Samples } \\
\text { Statistics }\end{array}$} & \multirow{2}{*}{$\begin{array}{l}\text { Paired } \\
\text { Differences } \\
\text { Mean }\end{array}$} & \multicolumn{2}{|c|}{ Paired Samples Test } \\
\hline & & & & Mean & SD & & $\begin{array}{l}\text { Wilcoxon } \\
\text { Test }\end{array}$ & $Z^{*}$ \\
\hline \multirow{2}{*}{1} & \multirow{2}{*}{ Sustainability of community } & \multirow{2}{*}{480} & $\mathrm{~A}$ & 2.58 & 1.12 & \multirow{2}{*}{-0.93} & \multirow{2}{*}{-15.283} & \multirow{2}{*}{0.000} \\
\hline & & & $\mathrm{E}$ & 3.51 & 1.37 & & & \\
\hline \multirow{2}{*}{2} & \multirow{2}{*}{ Community investment } & \multirow{2}{*}{480} & A & 2.83 & 1.21 & \multirow{2}{*}{-0.8} & \multirow{2}{*}{-14.702} & \multirow{2}{*}{0.000} \\
\hline & & & $\mathrm{E}$ & 3.63 & 1.13 & & & \\
\hline \multirow{2}{*}{3} & \multirow{2}{*}{ Community consultation } & \multirow{2}{*}{480} & A & 3.00 & 1.08 & \multirow{2}{*}{-0.63} & \multirow{2}{*}{-11.887} & \multirow{2}{*}{0.000} \\
\hline & & & $\mathrm{E}$ & 3.63 & 1.21 & & & \\
\hline \multirow{2}{*}{\multicolumn{3}{|c|}{ Grand mean }} & A & 2.80 & & \multirow{2}{*}{-0.79} & & \\
\hline & & & $\mathrm{E}$ & 3.59 & & & & \\
\hline
\end{tabular}

*Significance (2-tailed), Note: $\mathrm{A}=$ Actual, $\mathrm{E}=$ Expectation

Table 6. CSR towards environment

\begin{tabular}{|c|c|c|c|c|c|c|c|c|}
\hline \multirow{2}{*}{$\begin{array}{l}\dot{0} \\
\dot{Z} \\
\dot{\pi}\end{array}$} & \multirow{2}{*}{$\begin{array}{l}\text { Companies have } \\
\text { responsibilities } \\
\text { towards the } \\
\text { environment }\end{array}$} & \multirow{2}{*}{ 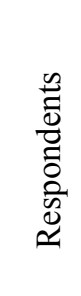 } & \multirow{2}{*}{ 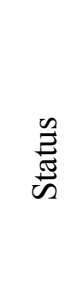 } & \multicolumn{2}{|c|}{$\begin{array}{l}\text { Paired } \\
\text { Samples } \\
\text { Statistics }\end{array}$} & \multirow{2}{*}{$\begin{array}{l}\text { Paired } \\
\text { Differences } \\
\text { Mean }\end{array}$} & \multicolumn{2}{|c|}{ Paired Samples Test } \\
\hline & & & & Mean & SD & & $\begin{array}{l}\text { Wilcoxon } \\
\text { Test }\end{array}$ & $Z^{*}$ \\
\hline \multirow{2}{*}{1} & \multirow{2}{*}{ Pollution } & \multirow{2}{*}{480} & A & 2.83 & 1.04 & \multirow{2}{*}{-0.58} & \multirow{2}{*}{-11.138} & \multirow{2}{*}{0.000} \\
\hline & & & $\mathrm{E}$ & 3.41 & 1.18 & & & \\
\hline \multirow{2}{*}{2} & \multirow{2}{*}{ Energy usage } & \multirow{2}{*}{480} & A & 2.93 & 1.07 & \multirow{2}{*}{-0.46} & \multirow{2}{*}{-9.057} & \multirow{2}{*}{0.000} \\
\hline & & & E & 3.39 & 1.23 & & & \\
\hline \multirow[b]{2}{*}{3} & \multirow{2}{*}{$\begin{array}{l}\text { Use of } \\
\text { non-renewable } \\
\text { resources }\end{array}$} & \multirow[b]{2}{*}{480} & A & 2.97 & 1.17 & \multirow[b]{2}{*}{-0.59} & \multirow[b]{2}{*}{-11.670} & \multirow[b]{2}{*}{0.000} \\
\hline & & & $\mathrm{E}$ & 3.56 & 1.18 & & & \\
\hline \multirow{2}{*}{4} & \multirow{2}{*}{ Urban renewal } & \multirow{2}{*}{480} & A & 2.87 & 1.05 & \multirow{2}{*}{-1.01} & \multirow{2}{*}{-14.921} & \multirow{2}{*}{0.000} \\
\hline & & & $\mathrm{E}$ & 3.88 & 1.54 & & & \\
\hline \multirow{2}{*}{\multicolumn{3}{|c|}{ Grand mean }} & A & 2.90 & & \multirow{2}{*}{-0.66} & & \\
\hline & & & $\mathrm{E}$ & 3.56 & & & & \\
\hline
\end{tabular}

*Significance (2-tailed), Note: A=Actual, E=Expectation 